\title{
Isolation of Aino Virus from an Aborted Bovine Fetus
}

\author{
Yukinori UCHINUNO, Yoshiharu NODA, Kazuki ISHIBASHI, Seiji NAGASUE, Hitomi SHIRAKAWA, \\ Masahiro NAGANO and Ryuichi OHE \\ Fukuoka Chuo Livestock Hygiene Service Center, 2-1-3 Isouda, Hakata, Fukuoka 816-0081, Japan \\ (Received 27 February 1998/Accepted 5 June 1998)
}

ABSTRACT. A male fetus of gestation day 187 was aborted from a Holstein-Friesian cow in an epizootic of the Aino virus (AINOV) in September 1995. Neutralizing antibody titers against AINOV were 1:128, 1:16 and 1:64 in the dam serum, fetal ascites and cerebrospinal fluid, respectively. A $10 \%$ brain suspension of the aborted fetus was prepared immediately after autopsy, rinsed three times and sonicated before centrifugation. The supernatant was then inoculated into HmLu-1 cell cultures. A cytopathic effect was noted on post-inoculation day 7. The isolated virus was identified as the AINOV based on the physicochemical properties and cross neutralization test. This is the first report on the isolation of AINOV from an aborted bovine fetus. - KEY wORDS: aborted bovine fetus, Aino virus, virus isolation.

J. Vet. Med. Sci. 60(10): 1139-1140, 1998

Since Aino virus (AINOV), a member of the Simbu virus group of genus Bunyavirus, originally isolated from mosquitoes (Culex tritaeniorhynchus) in Nagasaki Prefecture, Japan in 1964 [12], it was thereafter isolated from sentinel calves [3] and a dairy cow with sudden astasia and leukopenia [4]. A neutralizing antibody to AINOV was thereafter detected in precolostral serum of 2 calves manifesting the arthrogryposis-hydranencephaly(AH) syndrome in 1974 by Miura et al. [9]. AINOV was suspected to be one of the etiological viruses causing the AH syndrome as the Akabane virus.

Serotests of precolostral sera of fetuses with abnormal deliveries indicated a close relation with AINOV infection in western Japan $[1,2,8]$. In Fukuoka Prefecture, clustering of congenital scoliosis suspected of AINOV infection was observed in 10 bovine neonatals (4 stillbirths) from December 1990 to February 1991 [5]. However, isolation of AINOV from naturally infected bovine fetuses and calves or an indication of fetus infection, has not been established as yet.

A seroepidemiological survey in Fukuoka Prefecture in 1995 has revealed positive conversion of the antibody to AINOV; of 100 sentinel calves in 50 farms with an epizootic AINOV period between September and October [13], 1, 25 and 3 cases are found positive in September, October and November, respectively. A Holstein-Friesian male fetus of gestation day 187 was aborted in an epizootic of AINOV on September 23, 1995. Superficial layers of most cerebral and cerebellar sites were fused.

Antibodies to AINOV (JaNAr-28), Akabane virus (AKAV; JaGAr-39), Kasba virus (KASV; K-47), bovine diarrhea virus (BDV; Nose) and bovine herpesvirus 1 (BHV-
1; No. 758) were examined using serum of the dam as well as ascites and cerebrospinal fluid of the aborted fetus, according to the microtiter method of neutralization test [6].

Moreover, Antibodies to bluetongue virus serotype 21 (BTV-21; ON89-1) was tested by using a micro-gel diffusion test [7]. As shown in Table 1, Neutralizing antibody titers against AINOV were 1:128, 1:16 and 1:64 in the dam serum, fetal ascites and fetal cerebrospinal fluid, respectively. Antibodies to AKAV, KASV, BHV-1, BDV and BTV-21 were not found.

Bacteriologically, numerous Escherichia coli were isolated from principal organs and brain of the aborted fetus.

For virus isolation, a $10 \%$ cerebrum/cerebellum suspension was prepared immediately after autopsy with MEM (Eagle's minimam essential medium containing 10\% tryptose phosphate broth). The suspension was rinsed three times with MEM, processed with a $50-\mathrm{W}$ ultrasonic blender for $2 \mathrm{sec}$ before centrifugation at $1,000 \times \mathrm{g}$ for $5 \mathrm{~min}$ at $4{ }^{\circ} \mathrm{C}$. The supernatant, previously filtered through a membrane filter of 450-nm pore size, was inoculated into hamster lung cell line (HmLu-1) cell cultures before further incubation being cultured at $34^{\circ} \mathrm{C}$ in a roller drum with the maintenance medium containing 50\% MEM and 50\% GIT (Wako, Tokyo).

A cytopathic effect (CPE) was noted on post-inoculation day 7 . Virus isolation from the same material preserved at $-80^{\circ} \mathrm{C}$ was again attempted for the purpose of reconfirmation. CPE was noted on post-inoculation day 7 at the second passage.

Clones of the isolated virus were established by repeating limiting dilution three times with $\mathrm{HmLu}-1$ cell cultures before further tests.

Table 1. Antibodies against viruses related to the abnormal deliveries

\begin{tabular}{lcccccc}
\hline Sample & Aino & Akabane & Kasba & BHV-1 & BDV & Bluetongue \\
\hline Dam serum & $128^{\text {a) }}$ & $<2$ & $<2$ & $<2$ & $<2$ & -b) \\
Fetal ascites & 16 & $<2$ & $<2$ & $<2$ & $<2$ & - \\
Fetal cerebrospinal fluid & 64 & $<2$ & $<2$ & $<2$ & $<2$ & - \\
\hline
\end{tabular}

a) Neutralizing antibody titer. b) Antibody negative. 
Table 2. Cross-neutralization tests of the isolate, Aino, Akabane and Kasba viruses

\begin{tabular}{lcccc}
\hline \multirow{2}{*}{ Virus } & \multicolumn{4}{c}{ Antiserum } \\
\cline { 2 - 5 } & Isolate & Aino virus & Akabane virus & Kasba virus \\
\hline Isolate & $64^{\text {a) }}$ & 128 & $<4$ & $<4$ \\
Aino virus & 64 & 128 & $<4$ & $<4$ \\
Akabane virus & $<4$ & $<4$ & 1,024 & $<4$ \\
Kasba virus & $<4$ & $<4$ & $<4$ & 256 \\
\hline
\end{tabular}

a) Antibody titer.

The physicochemical properties of the virus were studied according to the method of Miura et al. [10]. Propagation of the isolated virus was not inhibited in a medium containing 5'-Iodo-2'-deoxyuridine. However, the isolated virus was inactivated with ether, chloroform and acid at $\mathrm{pH}$ 3.0. The isolated virus passed through a membrane filter with $220-\mathrm{nm}$ pore size. Infectivity of the isolated virus passing through the membrane filter with 100 -nm pore size was fairly reduced. The isolated virus could not pass through a pore size of $50-\mathrm{nm}$. These findings coincided well with those of AINOV JaNAr-28 tested as control.

Rabbit sera immuned to the isolated virus were prepared for serological studies. A series of cross neutralization tests were performed with AINOV (JaNAr-28), AKAV (JaGAr39) and KASV (K-47). These viruses and specific antisera (not the isolated virus) were gifts of the National Institute of Animal Health, Ministry of Agriculture, Forestry and Fisheries. The isolated virus showed a complete crossover with AINOV JaNar-28, confirming the candidate to be AINOV (Table 2).

The prior issue in this study was the isolation of AINOV from the brain of an aborted bovine fetus, because this would demonstrate that directly passed through the placenta of the dam. Regardless of the AINOV antibody in cerebrospinal fluid of aborted fetus, successful AINOV isolation was rendered possible by elimination of antibody components through rinse of the brain suspension, AINOV in neurocytes was then transmitted into the fluid due to cytoclasis by ultrasonic processing and wastage of AINOV was prevented by immediate inoculation after sonication.

No external deformities of the body or limbs of the fetus were seen, histopathological findings, however, have shown necrotizing encephalomalacic lesion in the brain. Additionally, AINOV antigen has also been confirmed in cytoplasm and perikarya of this brain stem lesion immunohistologically [11]. This suggests that the isolated AINOV may have caused these histopathological findings.

Abortion occurred at a time that corresponded to the climax of AINOV epizootic, followed by 46 abnormal deliveries occurring in Fukuoka Prefecture between December 1995 and April 1996. Serological studies strongly suggested AINOV to be the etiologic agent of epizootically induced abnormal deliveries [13]. This is further advocated by isolation of the virus from a naturally aborted fetus in an epizootic AINOV. Pathogenesis of the isolated AINOV should be further examined.

\section{REFERENCES}

1. Egashira, T., Itimaru, H., Yoshinaga, N., Enaga, N., Utikoshi, N. and Minamikawa, R. 1989. J. Jpn. Vet. Med. Assoc. 42: 94-96 (in Japanese with English summary).

2. Fukutomi, T., Ouchi, M., Okuda, K., Maruno, F. and Tabayashi, K. 1991. J. Jpn. Vet. Med. Assoc. 44: 17-19 (in Japanese with English summary).

3. Gard, G. P., Shorthose, J. E., Weir, R. P., Walsh, S. J. and Melville, L. F. 1988. Vet. Microbiol. 18: 109-118.

4. Ishibashi, K., Asada, K., Shirakawa, H., Nakamura, H. and Watanabe, A. 1992. J. Jpn. Vet. Med. Assoc. 45: 837-840 (in Japanese with English summary).

5. Ishibashi, K., Tomishita, Y., Shirakawa, H., Takaya, M. and Watanabe, A. 1994. J. Jpn. Vet. Med. Assoc. 47: 87-90 (in Japanese with English summary).

6. Ishibashi, K., Shirakawa, H., Uchinuno, Y. and Ogawa, T. 1995. J. Vet. Med. Sci. 57: 1-4.

7. Jochim, M. M. and Chow, T. L. 1969. Am. J. Vet. Res. 30: 33-41.

8. Kitano, Y., Yamashita, S., Furukawa, M. and Makinoda, K. 1993. J. Jpn. Vet. Med. Assoc. 46: 469-471 (in Japanese with English summary).

9. Miura, Y., Hayashi, S., Ishihara, T., Inaba, Y., Omori, T. and Matumoto, M. 1974. Arch. Gesamte Virusforsch. 46: 377 380.

10. Miura, Y., Goto, Y., Kubo, M. and Kono, Y. 1988. Am. J. Vet.Res. 49: 2022-2025.

11. Noda, Y., Uchinuno, Y., Shirakawa, H., Nagasue, S., Nagano, M., Ohe, R. and Narita, M. 1998. Vet. Pathol. (in press).

12. Takahashi, K., Oya, A., Okada, T., Matsuo, R., Kuma, M. and Noguchi, H. 1968. Jpn. J. Med. Sci. Biol. 21: 95-101.

13. Uchinuno, Y., Noda, Y., Shirakawa, H., Nagasue, S., Nagano, M. and Ohe, R. 1997. J. Jpn. Vet. Med. Assoc. 50: 709-712 (in Japanese with English summary). 